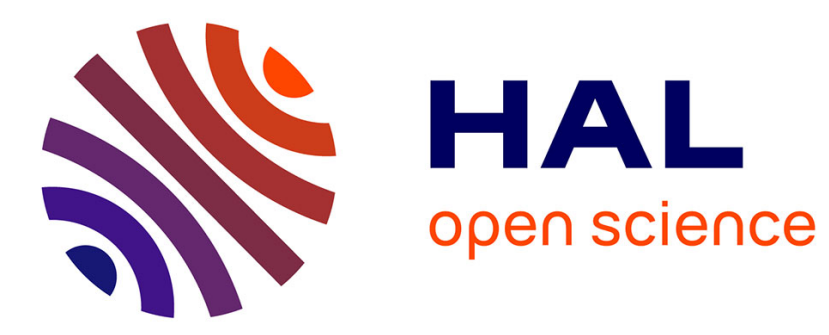

\title{
Recrystallization of silicon by pulsed lasers
}

\author{
J.C. Muller, C. Scharager, M. Toulemonde, P. Siffert
}

\section{To cite this version:}

J.C. Muller, C. Scharager, M. Toulemonde, P. Siffert. Recrystallization of silicon by pulsed lasers. Revue de Physique Appliquée, 1980, 15 (4), pp.865-868. 10.1051/rphysap:01980001504086500 . jpa00244797

\section{HAL Id: jpa-00244797 https://hal.science/jpa-00244797}

Submitted on 1 Jan 1980

HAL is a multi-disciplinary open access archive for the deposit and dissemination of scientific research documents, whether they are published or not. The documents may come from teaching and research institutions in France or abroad, or from public or private research centers.
L'archive ouverte pluridisciplinaire HAL, est destinée au dépôt et à la diffusion de documents scientifiques de niveau recherche, publiés ou non, émanant des établissements d'enseignement et de recherche français ou étrangers, des laboratoires publics ou privés. 


\title{
Recrystallization of silicon by pulsed lasers $(*)$
}

\author{
J. C. Muller, C. Scharager, M. Toulemonde and P. Siffert \\ Centre de Recherches Nucléaires \\ Groupe de Physique et Applications des Semiconducteurs (Phase) 67037 Strasbourg-Cedex, France
}

\begin{abstract}
Résumé. - Dans une première partie de ce travail on a calculé l'évolution de la température d'un film de silicium amorphe déposé sur un cristal de même nature en fonction de la puissance d'irradiation pour un laser pulsé rubis ou YAG. Les résultats obtenus ont été confrontés à diverses expériences au cours desquelles la recristallisation de films amorphes par laser a été mesurée par rétrodiffusion Rutherford (RBS). Le recuit laser conduit à un cristal de bonne qualité, toutefois des dommages subsistent, ainsi que l'ont montré des expériences de TSC et DLTS.
\end{abstract}

\begin{abstract}
Calculation of the evolution of temperature during pulsed laser annealing has been performed. The results are presented in directly useful figures for the two kinds of laser generally used (YAG, Ruby). The results are compared to various experimental measurements performed by RBS. If the crystallographic quality is quite good, TSC and DLTS measurements have shown that electrically active defects are still present after laser annealing.
\end{abstract}

1. Introduction. - The use of pulsed laser beams to recrystallize amorphous layers existing on top of single crystalline semiconductors like silicon, has recently been demonstrated in several laboratories [1-5]. In fact, two regrowth mechanisms have been observed, depending on the laser characteristics : either solid or liquid phase epitaxy regrowth. However, the exact mechanisms are still under discussion. Here, we will restrict ourself to conditions in which liquid phase epitaxy occurs. The applications of such a technique are quite obvious : solar cells, integrated circuits in semiconductor, doping of surface layers of solids... [6, 7]. For these applications, it is necessary to have models which allow an exact estimation of the optimal regrowth conditions. This is one of our goals. These models must be verified by the experience both from the point of view of crystal quality and from the residual electrical domage concentration. On this later point much less is available in the literature [8-10]. The experimental methods that we apply here, are Rutherford backscattering under channeling conditions (RBS) and thermally stimulated current (TSC) measurements.

2. Evaluation of the molten depth. - The dynamic of the physical evolution is described in term of a thermal transport model. A complete description of the used approach has been published elsewhere [11].

(*) Conférence présentée au Congrès de la Société Française de Physique (Toulouse).
Recently, other authors [12-14] published similar models, which are in agreement in first approximation, although they do not include temperature dependence of thermal and optical parameters. Recently Surko and al. [15] taking into account this dependence, suggest that the difference in the absorbed and calculated energy in a pulsed laser experiment on a virgin crystal can be reduced by reducing the reflectivity coefficient from 0.7 to 0.57 . By taking into account the latest value of 0.57 , we calculated the power density as a function of amorphous layer thickness for the various layers considered (Fig. 1).

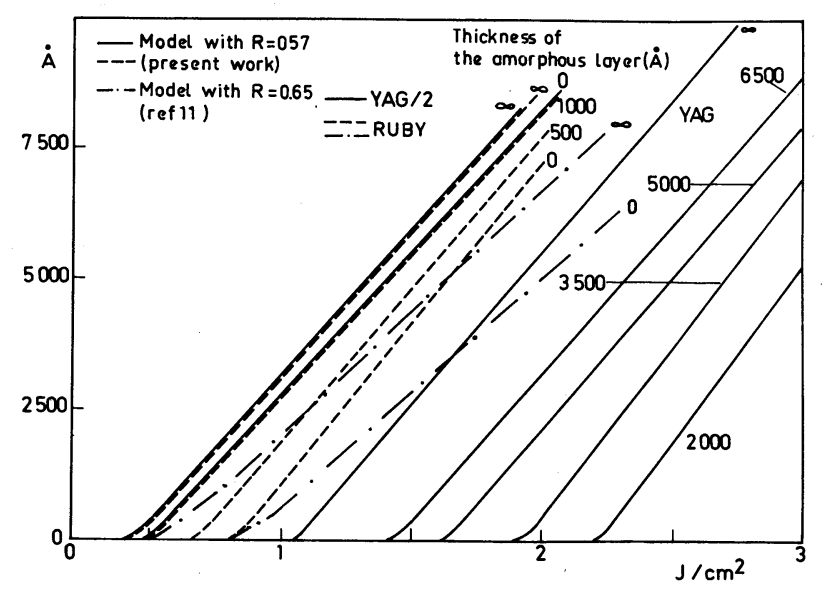

Fig. 1. - Thickness of molten silicon as a function of laser (Ruby and YAG) power density for amorphous silicon layers of various thicknesses. The two curves slash doted correspond to the reflectivity coefficients $(R=0.65)$ of the molten silicon. 
3. Measurement of the recrystallization by laser. 3.1 EXPERIMENTAL CONDITIONS. - 3.1.1 The samples. - Two kind of amorphous layers on single crystals have been used :

- amorphous silicon : thin films of amorphous silicon $(\mathrm{Si}(\mathrm{a}) \mathrm{H})$ have been deposited using silane glow discharge on a $\langle 111\rangle$ silicon substrate. The thickness and concentration of hydrogen ranged between 2000 $3000 \AA$ and $10-18 \%$. The absorption coefficient for photons of this material is well known [16].

- amorphized silicon : we have previously shown [17] that the $\mathrm{BF}_{3}$ glow discharge ion bombardment of silicon produces a completely amorphous layer, due to the high probability of nuclear collisions by the low speed molecular ions. $25 \mathrm{keV} \mathrm{BF}$ glow discharge produced a $1000 \AA$ thick amorphous layer on $\langle 111\rangle \mathrm{CZ}$ material for a total dosis of $3 \times 10^{16} \mathrm{~cm}^{-2}$ at current densities up to $1 \mathrm{~mA} / \mathrm{cm}^{2}$.

3.1.2 Laser annealing. - The laser illuminations have been performed in air with a ruby laser having the following characteristics : spot diameter at half power : $6 \mathrm{~mm}$, half width of pulse duration $25 \mathrm{~ns}$, power density up to $2 \mathrm{~J} / \mathrm{cm}^{2}$ and even $3.5 \mathrm{~J} / \mathrm{cm}^{2}$ on the central $2.5 \mathrm{~mm}$ in diameter area, repetition rate : $10 \mathrm{pulses} / \mathrm{min}$.

3.1.3 Crystal quality measurement. - Rutherford backscattering of $1 \mathrm{MeV}^{4} \mathrm{He}^{+}$ions was used under channelling conditions to investigate the amount and distribution of displaced atoms.

The backscattered particles have been detected by

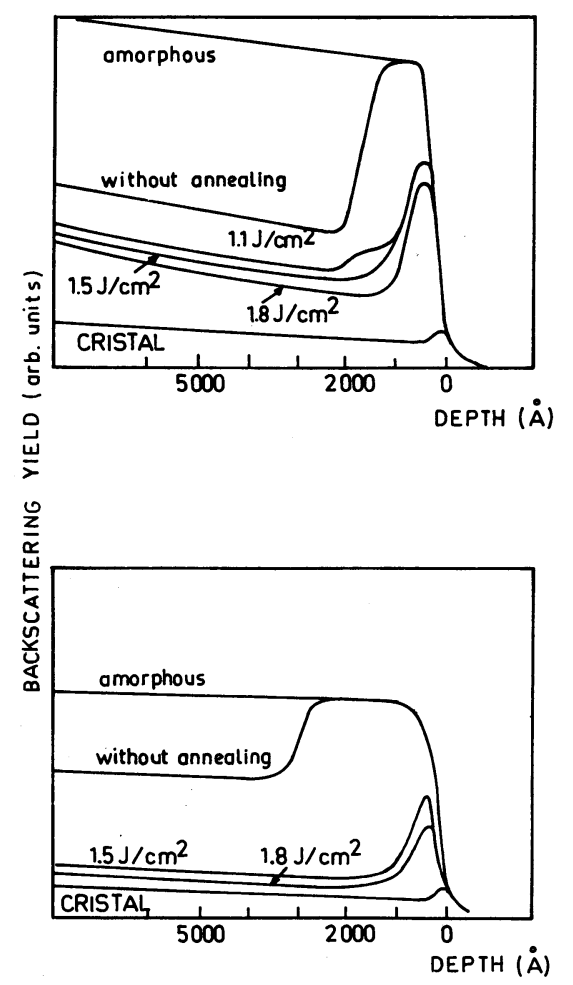

Fig. 2. - Rutherford backscattering spectra under channelling conditions of thin amorphous silicon films deposited on single crystals annealed under various ruby laser pulses. means of an electrostatic analyzer having a depth resolution of about $25 \AA$, which is more than ten times better than the conventional method used in the literature.

SIMS can also help to determine the conditions, where melting occurs, since in the melt complete redistribution of dopants implanted or diffused, occurs.

Finally, surface reflectivity of a continuous small power density laser allows in a storage oscilloscope to see the difference between crystalline, amorphous and liquid silicon.

3.2 Results. - 3.2.1 Si(a)H layers. - After irradiation with a $1.1 \mathrm{~J} / \mathrm{cm}^{2}$ pulse, RBS has shown that the layers are regrown, as expected from the model. However, if the crystalline-amorphous interface has become of very good crystallinity, a surface layer is still present which is not single crystalline (Fig. 2). Higher power densities are not noticeably modifying this situation. Furthermore, some hydrogen remains in the regrown zone, as indicated by nuclear reaction measurements.

3.2.2 Implanted layers. - Figure 3 shows the RBS analysis of the implanted surface layer, it appears that a high quality recrystallisation is obtained, but, as before, some crystal degradation is still visible on the top surface.

Measurements of the implanted layer sheet resistance as a function of power density indicated that at $0.8 \mathrm{~J} / \mathrm{cm}^{2}$ a strong reduction occurs, by SIMS we observed that impurity redistribution starts at power densities in excess of $0.8 \mathrm{~J} / \mathrm{cm}^{2}$.

It is interesting to notice at that point, that the recrystallisation by this laser pulse is much more efficient than a $30 \mathrm{~min}$. duration thermal annealing at $\left.950^{\circ} \mathrm{C} \mid 5\right]$. In fact, when reaching the melting temperature, all the preexisting radiation induced

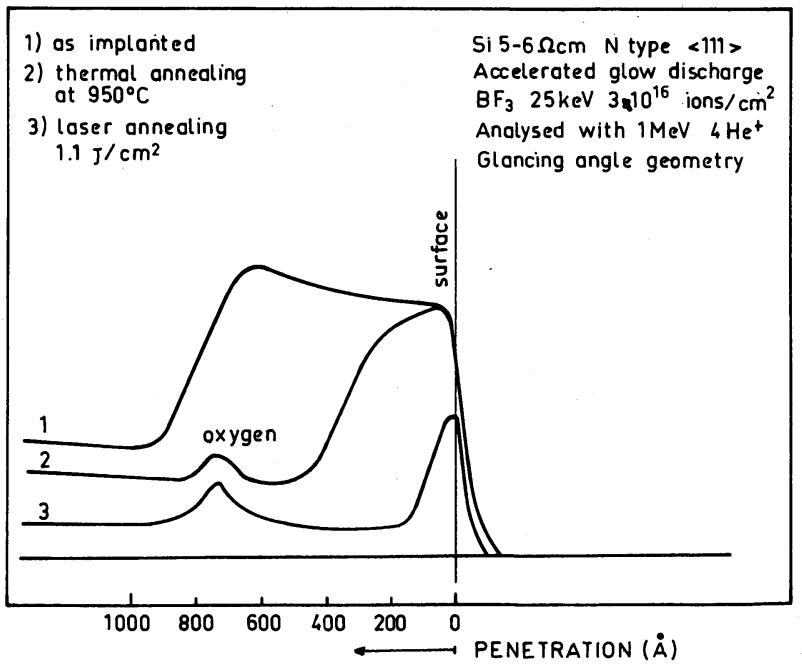

Fig. 3. - Backscattering spectra under channelling conditions and glancing angle geometry of a damaged layer annealed by a ruby laser pulse of $1.1 \mathrm{~J} / \mathrm{cm}^{2}$. For comparison the result of thermal annealing is also shown. 


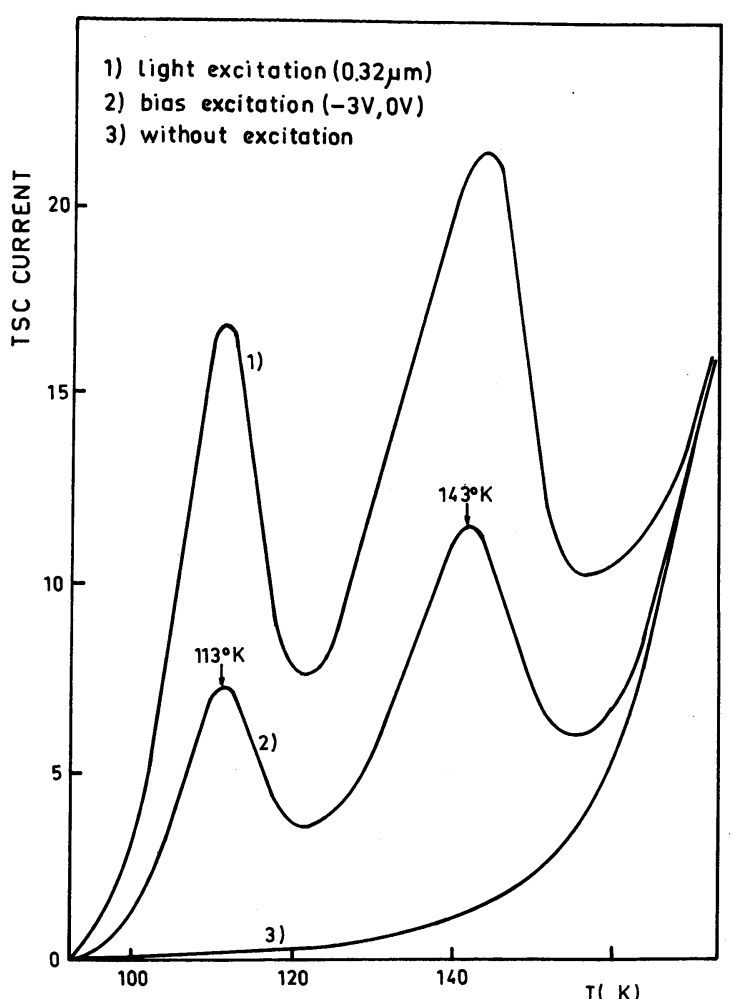

Fig. 4. - TSC curves recorded for $\mathrm{N}^{+} \mathrm{P}$ junction realized by $\mathrm{PF}_{5}$ glow discharge implantation at $15 \mathrm{keV}$ energy at a dosis of $10^{16} \mathrm{~cm}^{-2}$ followed by an $1.1 \mathrm{~J} / \mathrm{cm}^{2}$ ruby laser annealing.

stable complexes are dissociated and the epitaxial regrowth starts from a damage and contaminent free silicon region.

4. Electrical characteristics of the laser annealed zone. - 4.1 EXPERIMENTAL CONDITIONS. - For the TSC and DLTS measurements two types of samples have been employed :

- Virgin N-type FZ silicon of $1000 \Omega$.cm resistivity on which a gold Schottky diode was realized after laser irradiation.

- P-N junctions prepared on P-type FZ silicon of $150 \Omega . \mathrm{cm}$ silicon $\langle 111\rangle$ oriented by a glow discharge induced implantation from $\mathrm{PF}_{5}$. After the ion bombardment the amorphized layer was regrown by 1.1 and $1.4 \mathrm{~J} / \mathrm{cm}^{2}$ laser pulses.

4.2 Results. - A typical TSC spectrum is reported on figure 4 : two peaks appear, respectively around 113 and $145^{\circ} \mathrm{K}$. These peaks disappear only after an annealing at $450^{\circ} \mathrm{C}$ for $30 \mathrm{~min}$. (Fig. 5).

We tried to determine the main characteristics of these defect peaks : the first one at $113 \mathrm{~K}$ is an electron trap as measured by the method we published previously [18], its activation energy was calculated starting from different methods [19] and found to be $0.18 \pm 0.04 \mathrm{eV}$. The identification of the second peak is not completely done, its activation energy lies between 0.19 and $0.26 \mathrm{eV}$.

DLTS gave the same levels and on the virgin silicon



Fig. 5. - TSC curves obtained on the same implanted samples after $1.4 \mathrm{~J} / \mathrm{cm}^{2}$ laser annealing. The effect of a further thermal annealing at $450^{\circ} \mathrm{C}$ for $30 \mathrm{~min}$. is clearly visible.

having been laser irradiated the same results have also been seen indicating that the residual damage is not related to the implanted ion. It should be mentionned that the first TSC peak has also been observal by other authors [8] by $Q$ switched YAG laser annealing on FZ implanted silicon. They attributed its origin to the (V-O) vacancy-oxygen association at $\mathrm{E}_{\mathrm{c}}-0.17$ in the state $(0,-)$.

Today, all the defects due to laser irradiation have not been fully understood and much more work is necessary to clarify the situation.

5. Conclusion. - The laser induced regrowth of amorphous or damaged silicon surface layers has opened new possibilities for the realization of devices. However, if the crystal quality as seen by scanning microscopy (TEM) or Rutherford backscattering (RBS) is quasi-perfect, the electrical measurements shown that damages are still present at the microscopic scale. Until their origin will be clearly established it will not be possible to assertain that they could be brought under control.

Acknowledgments. - Many thanks are due to MM. Bourdon and Dumas who prepared the $\mathrm{Si}(\mathrm{a}) \mathrm{H}$ samples used in this study. 


\section{References}

[1] Kachurin, G. A., Pridachin, N. B., Smirnov, L. S., Sov. Phys. Semicond. 9 (1976) 946.

[2] Young, R. T., White, C. W., Clark, G. J., Narayan, J., Christie, W. H., Murakimi, M., King, P. W., Kramer, S. D., Appl. Phys. Lett. 32 (1978) 139.

[3] Foti, G., Rimini, E., Vitali, G., Bertolotti, M., Appl. Phys. 14 (1977) 189.

[4] Celler, G. K., Poate, J. M., Kimerling, L. C., Appl. Phys. Lett. 32 (1978) 464.

[5] Muller, J. C. A. and Grob, J. J., Stuck, R., Siffert, P., Appl. Phys. Lett. B 3 (1978) 287.

[6] Workshop on Laser Effects in Ion Implantation Semiconducteurs, Catania (1978) ed. Rimini.

[7] A.I.P., Proceedings $\mathrm{n}^{\circ} 50$ on Laser Solid Interactions and Laser Processing Materials Research Society Meeting, Boston (1978) ed. by S. D. Ferris, M. J. Leamy and J. M. Poate.

[8] Benton, J. L., Kimerling, L. C., Miller, G. L., Robinson, D. A. H., Celler, G. K. (conf. ref. 7) p. 543.

[9] Johnson, N. M., Gold, R. B., Lietolla, A. and Gibbons, J. K. (conf. ref. 7) p. 550.

[10] Zignani, F., Galloni, R., Pedulli, L., Bentini, G. G., Servidori, M., Cembali, F., Desalvo, A., 1979 European Photovoltaic Solar Energy Conference, Berlin (West Germany), p. 213, ed. by O. Reidel.
[11] Bell, R. O., Toulemonde, M. and Siffert, P., Appl. Phys. 19 (1979) 313.

[12] Baeri, P., Campisano, S. U., Foti, G. and Rimini, E., Appl. Phys. Lett. 33 (1978) 137 and J. Appl. Phys. 50 (1979) 788.

[13] Wang, J. C., Wood, R. F. and Pronko, P. P., Appl. Phys. Lett. 33 (1978) 455.

[14] Kharbullin, I. B., Shtyrkov, E. I., Zapirov, M. M., Bayzitov, R. M. and Galjamichinov, M. F., Rad. Effects 36 (1978) 225.

[15] Surko, C. M., Summons, A. L., Auston, D. H., GolovChenko, J. A., Slusher, R. E. and Venkatesan, T. N. C., Appl. Phys. Lett. 34 (1979) 635.

[16] Perrin, J., Solomon, I., Bourdon, B., Fontenille, J., Ligeon, E., Thin Solid Film 16 (1979) 327.

[17] Muller, J. C., Ponpon, J. P. and Grob, A., Stuck, R., Siffert, P., Photovoltaic Solar Energy Conference European, Luxembourg (1977), p. 897, ed. by D. Reidel.

[18] Muller, J. C., Stuck, R., Berger, R., Siffert, P., Solid State Electron 17 (1974) 1293.

[19] Stuck, R., Muller, J. C., Ponpon, J. P., Scharager, C., Schwab, C., Siffert, P., J. Appl. Phys. 47 (1976) 25. 